\title{
水电站工程建设施工安全管理探究
}

\author{
李昊晏 靳永卫 吴小林 楼易承 宋云鹤
}

浙江缙云抽水蓄能有限公司

DOI:10.32629/hwr.v3i12.2519

[ 摘 要] 水电站工程建设施工是一项非常复杂的工程, 施工人员众多, 施工范围也比较大, 还会涉及到特种作业, 所以水电站工程建设施工的特 点决定了施工安全管理的重要性。在水电站工程建设施工的过程中, 如果出现了安全隐患, 将会造成重大的人员及财产损失, 造成比较严重的社 会影响。我国现在很多的水电站工程建设施工存在安全管理问题。本文通过对水电站工程建设进行研究,分析施工中的安全管理。

[关键词] 水电站; 工程建设; 安全管理

水电站工程建设的过程中, 潜在很大的安全风险, 增加了工程事故的 发生机率。水电站施工中, 涉及到诸多安全作业, 如: 高空、爆破等, 需采 取安全管理的方式, 加强安全管理的力度, 满足水电站工程建设的需求。安 全管理是水电站工程建设的必需途径, 全面应用到水电站建设中, 维护水 电站的安全建设, 同时体现安全管理的价值意义。

\section{1 加强水电站工程建设施工安全管理的作用}

在当前社会经济全面发展背景下, 水电工程也得到了良好发展, 在此 背景下, 也给水电工程施工提出了严格的标准。怎样凭借有限的资源实现 科学分配, 促进水电工程的稳定发展, 是当前有关部门重点关注的问题。水 电工程建设作为一个利国利民的工程项目, 其可以对自然灾害起到防洪抗 涝的效果, 并且还要促进水资源的高效应用, 给国民经济增长提供条件。然 而, 从实际情况来说, 在开展水电站工程施工工作时, 因为自身含有施工规 模大、施工流程多等特性, 一旦其中一个施工环节存在问题, 必将会给整个 工程施工安全带来影响, 轻者造成工程返工, 给企业带来一定经济损失, 重 者将会给施工人员人身安全埋下隐患。因此, 为了减少问题出现, 就要给予 施工安全管理工作高度注重, 根据具体情况, 加大施工安全管理力度, 提升 相关人员专业素养, 确保每个职工均树立良好的安全施工意识, 防止不必 要问题出现, 保证整体水电工程施工安全。

\section{2 水电站工程建设施工存在的安全管理问题}

2. 1缺乏专业的安全管理人员

水电站工程在建设施工过程中缺乏专业的安全管理人员, 由于水电站 工程的施工线路比较长, 施工范围也比较广, 很多安全管理人员不仅要对 施工安全性进行管理, 还需要对施工质量和施工环境进行管理, 解决水电 站工程施工的移民问题。现在很多水电站工程的建设施工仅有三到五个安 全管理人员, 不能满足施工现场的安全管理要求。另外安全管理人员的专
业水平都比较低, 缺乏专业性技能。安全管理人员的知识水平出现严重两 极分化现象, 年轻的管理人员管理经验不足, 不能对水电站工程的建设施 工进行全面的安全管理。

\section{2 部分水电站工程对施工安全管理不够重视}

水电站工程的建设施工大多比较重视施工进度, 以便为施工企业创造 良好的经济效益, 却忽略了对施工安全的管理, 而且施工安全管理人员原 本就存在不足的现象, 又要对施工质量和施工环境等进行监管, 使施工安 全管理力度更加薄弱。施工安全管理人员的权利存在明显不足的现象, 在 安全管理的过程中, 不能对某些安全管理制度进行有效的落实。施工企业 也没有对各项施工组织及时的进行安全检查, 施工安全检查工作过于注重 形式, 忽略的安全检查的实际意义。

\section{3混凝土浇筑安全管理体系不完善}

在水电站工程建设的后期, 需要进行大量的混凝土浇筑施工。混凝 土工程的质量要求比较高, 运输任务比较重, 而且随着水电站坝体的增 高, 肯定会进行高空作业, 所以混凝土浇筑施工的难度比较大。在混凝土 浇筑施工的过程中, 需要进行严格的安全管理, 保证水电站工程的整体 建设质量。

\section{4水电站工程建设施工安全管理经费投入不足}

很对施工企业为了得到水电站工程项目的施工, 在招投标环节中以压 低价格的方法中标, 但是因为标价过低, 导致建设施工过程中, 安全管理经 费的投入出现明显不足的现象。由于施工单位在最开始签订水电站工程建 设施工项目时, 安全管理费用是分期进行支付的, 与施工过程中的工程量 没有太大的关系, 导致安全管理经费与实际的生产过程脱节, 不能产生实 际的安全管理效果。另外还有一些施工单位在投入安全管理经费之后, 没 有取得良好的效果, 所以就降低了安全管理经费的投入。

项目管理质量无法有效提高。因此, 在管理方面, 相关企业多注入创新型管 理人才, 优化管理层结构, 提高管理层的综合素质, 为保障项目管理成员能 在知识技能层面相匹配。对管理意识薄弱的人员进行培训, 增强其管理意 识, 相互交流管理经验, 明确管理层的管理工作和应尽义务。

3. 5 做好项目成本管理。项目工程的建设中, 成本管理是在计划中保证 工程质量下运用的方法, 对项目的成本进行监督管理, 发生偏差时能及时 纠正, 保证支出, 能够将成本严格控制在范围内。合理的成本管理体现在减 少资金投入, 减短建设工期, 提高经济效益。所以, 做好项目成本管理是非 常重要的, 引进创新的成本管理概念, 在环境发生变化时能够及时调整项 目成本, 制定合理的施工方案, 保证项目质量并且降低施工成本。

\section{4 结语}

条件, 通过对电力工程进行管理, 进而提升电力企业的服务能力。全管理工 作是影响电力项目的一个重要因素, 只有采取科学、合理的管理措施, 才能 公整体上提升电力工程项目的专业水平。但是随着电力企业的建设和发展, 还会出现各种新问题, 作为管理层一定要根据实际情况进行积极的探索, 以保证电力系统的安全运行。

\section{[参考文献]}

[1]沈亮.电力工程项目施工阶段进度费用联合控制研究[D]. 重庆大 学,2004.

[2]胡龙舟.电力工程项目管理过程中的风险控制及解决措施探究 [J]. 科技创新与应用,2019,(12):191-192.

[3]宋俊武, 邓云祥. 对供电公司电力工程项目管理研究 [J]. 现代工业经 济和信息化,2019,9(03):102-103. 
2. 5施工安全管理部门内安全管理人员的权责不平衡

在水电站工程建设施工过程中, 很多安全管理人员不愿意从事安全 管理工作, 因为安全管理工作的责任比较重大, 管理疏忽就会承担严重 的责任, 但是管理过于严格还容易得罪他人, 产生吃力不讨好的现象。另 外安全管理任务比较繁重, 需要管理的内容比较多, 但却较难受到领导 的重视, 而且安全管理人员的薪资水平比较低。这种权责不平衡的现象 导致水电站工程建设施工安全管理不够严格, 而且还产生了严重的人员 流失现象。

2.6 水电站工程建设施工的过程中经常会出现习惯性违章现象

水电站工程建设施工的过程中, 很多施工人员会出现习惯性违章现象, 将一些违反安全操作的不良习惯带入到施工过程中。例如不佩戴安全帽、 货车超载现象、高空施工安全保护措施不足的现象。这些现象称为了引发 施工安全事故的主要原因, 施工人员的习惯性违章和施工现场的安全监管 有着很大的关系, 需要提高施工人员的安全意识, 加强对施工人员的安全 培训等等。

\section{3 水电站工程建设施工的安全管理措施}

3.1 业主单位需要加强对水电站工程建设的安全监督

业主单位可以定期召开安全会议, 对水电站工程建设施工中存在的安 全隐患进行分析, 提出有效的解决措施。在工程施工过程中, 安全管理人员 要带头学习安全生产知识, 并遵循各项规章制度, 起到模范带头作用, 并定 期对水电站工程施工进行安全检查。施工单位还要组织各项安全教育活动, 完善施工安全管理制度。

3. 2 加强对安全管理制度的宣传教育, 实现教育工作与安全监督工作 的有机结合

在水电站工程建设施工的工程中, 任何不安全行为都是人为因素引 发的, 所以需要对施工人员的不安全行为进行纠正, 消除不安全因素对 整个工程施工的影响。在水电站工程建设施工的安全管理过程中, 始终 把人摆在第一位, 加强对施工人员的安全教育, 并组织安全生产活动, 开 展各类知识竞赛和施工技术比赛, 为水电站工程的施工营造一个良好的 环境。

在工程施工过程中, 重视人性化管理, 重视施工人员的思想教育工作, 使施工人员的安全意识不断提高。安全教育工作还要与安全监督工作有机 的结合起来, 为水电站工程的安全施工打下坚实的基础。

3. 3建立完善的安全监督机构对水电站工程建设施工进行监督

为了保证工程施工安全性, 在建设施工初期就要建立起完善的安全监 督机构, 对水电站工程的建设施工进行统一管理, 通过定期或者不定期的
安全检查, 对施工过程中的不安全行为进行处罚。对水电站工程建设施工 进行安全管理, 还需要对安全监督网络进行完善, 成立单独的安全监督小 组, 有效解决施工进度和施工质量之间的矛盾。建立完善的安全监督机构 是确保水电站工程安全施工最基础的保障。

3. 4建立施工过程的安全保证体系

在水电站工程建设施工过程中, 要严格的进行施工安全管理, 确保安 全岗位随时有安全管理人员上岗, 对施工现场进行安全检查, 可以及时解 决工程中存在的安全隐患。施工过程的安全保证体系要坚持做好对施工准 备阶段、正常施工阶段和竣工阶段的安全检查, 并进行相应的记录, 确保整 个工程施工的安全性。

3.5 水电站工程关键环节的安全管理

在对水电站的拦河坝进行施工时, 要加强对施工通道的安全疏导, 并 在关键位置设置警示标志。在拦河坝的危险路段设置安全防护墙, 保证车 辆设备进出安全。在对引水隧道进行施工时, 要搭设专门的移动防护架, 并利用喷浆支护结构对隧道进行支护, 保证施工人员的安全。在对水电站 的厂区高边坡进行施工时, 要采取边开挖边支护的方式进行施工, 并在施 工范围布置警戒线, 安全专门在现场进行施工安全管理。

3.6 保证安全管理费用的投入和使用

在水电站工程建设施工过程中, 对安全管理费用进行单独管理, 并有 计划的投入到工程施工中。安全管理费用的使用要严格的按照计划进行, 并有施工负责人进行控制, 保证费用使用的明确性, 使安全管理费用可以 全部投入到水电站工程的施工安全管理中。

\section{4 结语}

水电站工程建设的过程中, 深化施工安全管理的应用, 用于约束水电 站施工中的各项行为, 降低水电站施工作业的风险率, 最主要的是维护水 电站工程的安全, 优化工程施工的环境, 全面发挥安全管理的优势。水电站 工程建设在实施安全管理的过程中, 还要落实控制策略, 目的是辅助水电 站工程的安全管理, 确保水电站工程的稳定性。

\section{[参考文献]}

[1]王虎,游萍.水电站施工安全管理[J].科技创新与应用,2012,(16):148.

[2]张祥.试论水电站施工程建设施工安全管理 [J]. 四川水 泥,2018,(10):180.

[3]㚞启华.水电站工程建设施工安全管理策略之研究 [J].科技资 讯,2018,16(18):73+76.

[4]张秋红.试论水电站工程建设施工安全管理 [J]. 江西建 材,2016,(02):110+107. 